\title{
ESTIMATION OF A PRODUCTION FUNCTION FOR PHILIPPINE RETAIL STORES
}

\author{
Jason C. Patalinghug ${ }^{1}$
}

date of paper receipt:

date of sending to review:

date of review receipt:

21.03.2019.

25.03.2019.

03.04.2019.

Review Article

doi:10.2478/eoik-2019-0006

UDK: 658.871:005.932(914)

${ }^{1}$ Department of Economics and Finance, Southern Connecticut State University, USA

\begin{abstract}
The purpose of this paper is the estimation of a production function for retail stores in the Philippines. A generalized Cobb-Douglas production function is utilized for this purpose. Ordinary Least Squares is used in obtaining the coefficients for labor and capital. The results show that the marginal product of labor to be higher than the marginal product of capital and the hypothesis of constant returns to scale is not rejected.
\end{abstract}

Keywords:

production function, retail industry, Philippines 


\section{INTRODUCTION}

The Philippine retail trade industry carries a wide array of products such as food, textile and apparel, construction materials, books, office and household appliances, transport equipment and accessories, drugs, mechanical supplies and equipment, petroleum products, toys, gifts, and jewelry products.

The growing importance of the retail-trade sector to the Philippine economy is one major factor behind repeated attempts since 1993 to liberalize the sector. In March of 2000, the Retail Trade Liberalization Act of 2000 (Republic Act 8762) was passed into law by the Philippine Congress. This law opened up the retail trade sector to foreign investment.

Table 1 shows that as the Philippine economy grew in the period 1992 to 2006, the share of retail trade in both Gross Domestic Product (GDP) and Gross National Product (GNP) has remained at about the same level (between 10-13\% of both GNP and GDP). The average ratio of retail trade gross value added to GNP for the period 1992 to 2006 is approximately 0.112 while the average ratio of retail trade gross value added to GDP for the period 1992 to 2006 is approximately 0.118 . The retail sector grew by an average of 5.8\% from 1981 to 1997 compared to average GDP growth of $2.27 \%$ for the same period. In 1997, its share in the services sector and trade subsector was approximately 25.43 percent and 72.84 percent, respectively (Digal, 2001).

Table 1. Philippine Retail Gross Value Added (RTGVA), Gross Domestic Product (GNP), Gross National Product (GNP) and Associated Ratios (in thousand Philippine Pesos)

\begin{tabular}{|c|c|c|c|c|c|}
\hline Year & $\begin{array}{c}\text { Retail Trade } \\
\text { Gross Value } \\
\text { Added (RTGVA) }\end{array}$ & GNP & GDP & $\begin{array}{c}\text { Ratio of } \\
\text { RTGVA to } \\
\text { GNP }\end{array}$ & $\begin{array}{c}\text { Ratio of } \\
\text { RTGVA to } \\
\text { GDP }\end{array}$ \\
\hline 1992 & 80,305 & 731,396 & 718,941 & 0.110 & 0.112 \\
\hline 1993 & 81,757 & 751,479 & 734,156 & 0.109 & 0.111 \\
\hline 1994 & 85,386 & 786,136 & 766,368 & 0.109 & 0.111 \\
\hline 1995 & 90,389 & 824,525 & 802,224 & 0.110 & 0.113 \\
\hline 1996 & 95,816 & 884,226 & 849,121 & 0.108 & 0.113 \\
\hline 1997 & 99,605 & 930,658 & 893,151 & 0.107 & 0.112 \\
\hline 1998 & 103,151 & 934,481 & 888,000 & 0.110 & 0.116 \\
\hline 1999 & 108,693 & 969,334 & 918,160 & 0.112 & 0.118 \\
\hline 2000 & 115,814 & $1,037,856$ & 972,960 & 0.112 & 0.119 \\
\hline 2001 & 120,533 & $1,061,283$ & 990,042 & 0.114 & 0.122 \\
\hline 2002 & 127,714 & $1,105,695$ & $1,043,094$ & 0.116 & 0.122 \\
\hline 2003 & 135,292 & $1,171,431$ & $1,085,072$ & 0.115 & 0.125 \\
\hline 2004 & 144,691 & $1,252,331$ & $1,154,295$ & 0.116 & 0.125 \\
\hline 2005 & 152,963 & $1,319,107$ & $1,210,497$ & 0.116 & 0.126 \\
\hline 2006 & 163,856 & $1,399,527$ & $1,276,435$ & 0.117 & 0.128 \\
\hline
\end{tabular}

Source: National Statistics Office of the Philippines

Some analytical questions which revolve around the productivity of retail services must be answered if the retailing sector of the economy is to be better understood. Such analysis is of use to government policy makers in formulating public policy. It is likewise useful to industry leaders who are trying to assess how much output they can derive from existing resources.

The purpose of this paper is the estimation of a production function for retail stores in the Philippines. The paper investigates the how labor and capital interact in the Philippine retail sector. An understanding of the retail trade industry, which is an important segment of the Philippine 
economy, is needed to manage the economy effectively in the 21 st century. It would also enable government officials to formulate policies that would benefit the retail industry.

\section{REVIEW OF RELATED LITERATURE}

Ingene and Lusch (1999) tried to model the economics of retail store operation by formulating a production function showing the relative inputs of labor and capital required. By formulating this function, they were able to show the productivity of these factors in the U.S. retail sector. They were able to discover positive and significant relationships between the dependent variable (sales per store) and both employee labor hours and total store floor space. Their paper had three main findings. First, they did not reject their hypothesis of constant returns to scale in department stores. Second, the elasticity of labor was higher than that of capital which implies that additional labor is more productive than additional capital. Their third finding was about regional differences in productivity. These differences were hypothesized to be a function of the age of the capital stock and the quality of labor. Ingene and Lusch (1999) found out that there have been changes in the technology used by department stores, some of which is dependent upon construction of new stores and some of which is easily adaptable to "old" stores.

Ofer (1973) used a cross section of retail stores in Israel to estimate genuine scale effects in retail trade. He did this by estimating a simple production function by using the Cobb-Douglas structure with labor and capital as inputs and value added as output. Aigner and Chu (1968) showed a technique to estimate a production function that shows maximum obtainable product that could be obtained from available input combination and technology.

Tilley and Hicks (1970) looked at the relationship between supermarket size and various aspects of operating performance. Ingene and Lusch (1982) analyzed the determinants of productivity and productivity change in the retail sector and they found a negative relationship between store size and labor productivity. McAnally (1963) reviewed some of the concepts of retail output used to measure productivity. Ratchford and Brown (1985) used a general production function to study productivity gains and losses for various outputs of food retailing over the period 1959 to 1979.

Several studies have investigated means of detecting economies of scale. McClelland (1967) examined the ratio of profit to capital, the ratio of inventory to sales, the ratio of gross profit to sales and the ratio of wages to sales. If there were economies of scale the ratio of wages to sales would decrease while the other three ratios would increase (Ingene and Lusch, 1999). Tilley and Hicks (1970) also had a similar methodology. Ingene and Lusch (1999) did not use the methodology of McClelland and Tilley and Hicks because they believe that this approach is only valid if all firms pay the same prices for labor and capital.

The retail sector was chosen for this paper because it is the sector with which customers have the most direct contact (Ingene, 1982). Kendrick (1973) and Takeuchi and Bucklin (1977) mentioned that the growth rate of labor productivity in the retail sector has been lower than in other major sectors of the U.S. economy in the postwar period.

Recent research has examined the productivity and efficiency of retail stores. Gauri (2013) found that stores with larger selling areas, more check-out counters and are located closer to their competition had the best efficiency. Assaf, Barros and Sellers-Rubio (2011) found that stores with lower price strategy, longer existence in the market, and multiple geographical presences are more efficient than stores that do not possess these characteristics.

Shin and Eksioglu (2015) studied the relationship between radio frequency identification technology and the labor productivity. Using the Cobb-Douglas production function in their regression analysis, they show that retailers using RFID technology have higher labor productivity compared to those that do not use the technology.

Hossain, Majumder and Bazak (2012) used the Cobb-Douglas production function to measure the production processes of various industries in Bangladesh. They found out that some industries like 
pharmaceuticals and furniture exhibit economies of scale while other industries such as tobacco and printing exhibit diseconomies of scale.

Constantin, Martin and Rivera (2009) used several techniques to measure the productivity of the Brazilian agribusiness sector. Using the Cobb-Douglas function, they discovered that harvested area and agricultural credit are the two most important factors in agricultural production. The use of limestone to correct for soil acidity is also an important factor of production.

Ayaz and Hussain (2011) used stochastic frontier analysis to measure the efficiency of the farming sector in the Faisalabad district of Punjab province in Pakistan. Their Cobb-Douglas estimates show that fertilizer nutrients and cash inputs such as land preparation cost and seed cost have the most significant effects on farmers' incomes. The provision of irrigation and livestock expenditures also have a significant impact on the income of farmers.

Lastly, Chen, Niebel and Saam (2016) examined information and communications technology (ICT) intensive industries in Europe. They estimated a production function and discovered that intangible capital has a larger effect on ICT-intensive sectors as opposed to those which are not ICT-intensive.

\section{MODEL AND METHODOLOGY}

The study of productivity in retailing is meant to address whether resources are utilized efficiently. In economic theory, the production function framework is utilized to analyze the productivity of capital, labor, or both. Several studies (Tilley and Hicks, 1970; Ofer, 1973; and Ingene and Lusch, 1978) have applied the production function analysis to U.S. retailing.

Although there are several explicit forms in specifying a production function, we have chosen to utilize a generalized Cobb-Douglas production function because it is relatively well-known and easy to use. The estimation of a production function for retail stores will therefore begin with a Cobb-Douglas function:

$$
\mathrm{Y}=\beta_{0} \mathrm{~K}^{\beta 1} \mathrm{~L}^{\beta 2} \mathrm{e}^{\mu}
$$

where $\mathrm{Y}=$ output of retail stores

$\mathrm{K}=$ capital input in retail stores

$\mathrm{L}=$ labor input in retail stores

$\mathrm{e}=$ base of the Napierian logarithms

$\beta_{0}, \beta_{1}, \beta_{2}=$ parameters to be estimated

$\mu=$ error term

Each parameter in (1) has a meaningful interpretation. The elasticity of retail output with respect to capital input is represented by $\beta_{1}$. Similarly, $\beta_{2}$ is the elasticity of retail output with respect to the labor input. The term $\beta_{0}$ is a technology parameter.

Since many stores exist in major Philippine retail markets, it is assumed that retail business in the Philippines is highly competitive. In a generalized Cobb-Douglas model, b1 and b2 are not restricted to sum to unity. In this situation, capital and labor are assumed to be paid in proportion to their output elasticities.

In estimating equation (1) through the use of a multiple regression analysis, we naturally have to make a linear transformation of equation (1), via logarithmic transformation, to arrive at equation (2):

$$
\ln Y=\ln \beta_{0}+\beta_{1} \ln K+\beta_{2} \ln L+\mu
$$




\section{DATA}

The data for this study comes from the 1983, 1988, 1994 and 2000 Census of Establishments: Wholesale and Retail Trade (CE). Each CE contains cross-sectional data on retail sales, value added, total employment, total compensation, and book value of fixed assets at the regional level (including the National Capital Region).

Since establishments differ greatly in size regressions will be done based on the three store categories provided by the CE: large stores, small stores, and all stores. For each category, there are 58 regional observations that were gathered from the CEs.

The concept of output in retail trade differs from that in manufacturing. The latter measures its output in physical units, but the former measures its output as a combination of physical items and services rendered. Output should be measured in peso units to capture the service component of output which is intangible. The dependent variable used in this study is total sales divided by the number of establishments. This would serve as a proxy for average output per store.

The CE reports both total number of employees and total compensation for retail stores per region. The labor input used in this study is the total number of retail employees divided by the number of establishments. This is called the L variable in our regression equations. Unfortunately, the CE does not disaggregate the data on total number of retail employees into whether these employees are working full-time or part-time. As an alternative specification, we use total compensation divided by the number of establishments as the labor input in some additional regression runs. This variable is defined as COMP in the regression equations.

The capital input used in this study is the book value of fixed assets divided by the number of establishments. This variable is defined as $\mathrm{K}$ in the regression equations. The capital variable is a combination of land, buildings, and equipment utilized by retail stores. Accounts receivables and inventories (working capital) are important in retail trade business. However, the CE does not have data on accounts receivables, but it contains data on inventories. Even if data on accounts receivable were available it may not be appropriate for use in a production-function analysis. Both accounts receivables and inventories are highly correlated with sales. (This is the conclusion of some empirical studies for U.S. retailing.) Thus, their inclusion will introduce multicollinearity in the results. Since sales, compensation, and book value of fixed assets are in pesos, the inflation rate may have affected our parameter estimates because we are using time-series data (1983, 1988, 1994 and 2000). To control for inflation, we deflated the variables for sales, book value of fixed assets and compensation in peso units using the implicit price index (IPI) for retail trade $(1985=100)$ as the deflator.

\section{HYPOTHESES}

A set of hypotheses concerning the impact of factor inputs on retail store output is developed in this section.

The most frequently discussed determinants of retail productivity are the size of stores, the capital to labor ratio, and the degree of competition.

The following three hypotheses will be tested:

\section{Hypothesis 1 (H1)}

An increase in capital in retailing in a geographical market, holding other factors constant, will not affect output.

$\mathrm{H}_{\mathrm{O}}: \beta_{1}=0$ accept hypothesis 1

$\mathrm{H}_{1}: \beta_{1} \neq 0$ reject hypothesis 1 


\section{Hypothesis 2 (H2)}

An increase in the number of retail workers in a geographical market, holding other factors constant, will not affect output.

$\mathrm{H}_{\mathrm{O}}: \beta_{2}=0$ accept hypothesis 2

$\mathrm{H}_{1}: \beta_{2} \neq 0$ reject hypothesis 2

\section{Hypothesis 3 (H3)}

The sum of the coefficients of capital and labor inputs is equal to 1 .

$\mathrm{H}_{\mathrm{o}}: \beta_{1}+\beta_{2}=1$ accept hypothesis 3

$\mathrm{H}_{1}: \beta_{1}+\beta_{2} \neq 1$ reject hypothesis 3

If Hypothesis 1 is rejected then that means that an additional unit of capital, holding labor constant, will increase output. If Hypothesis 2 is rejected then that means that an additional unit of labor, holding capital constant, will affect output. If Hypothesis 3 is not rejected then we achieve constant returns to scale (CRS). Constant return to scale implies that all of the output is used up to pay for capital and labor. If Hypothesis 3 is rejected then we do not achieve constant returns to scale and thus we would have either decreasing returns to scale $\left(\beta_{1}+\beta_{2}<1\right)$ or increasing returns to scale $\left(\beta_{1}+\beta_{2}>1\right)$. If stores had increasing returns to scale we would expect to see few, if any, small stores since larger stores would be more efficient and would be able to cut prices so as to drive the smaller stores from the market. If there were decreasing returns to scale relatively large stores would be less profitable than smaller stores. A profit maximizing entrepreneur thus would not build an excessively large store. Constant returns to scale thus implies that both large and small stores have a chance to survive thus ensuring a more competitive market.

I would expect to see both Hypothesis 1 and 2 rejected. Both additional capital and additional labor in my opinion have an effect on a store's output. I would expect Hypothesis 3 not to be rejected since the presence of both large and small stores in the Philippine market implies that there is room for everyone.

\section{RESULTS}

Several production functions were estimated using the Cobb-Douglas form. Table 1 presents the results of estimating the production function for Philippine retail stores. Three types of store groupings are used: small stores (with less than 10 workers), large stores (with 10 or more workers), and all stores (the sum of small and large stores) based on definitions provided by the National Statistics Office (NSO) of the Philippines. Two alternative labor-input variables are used: (1) number of employed workers per store (L), and total compensation per store (COMP). Specifications (1), (3), and (5) use L as the labor input for small, large, and all stores, respectively. On the other hand, specifications (2), (4), and (6) use COMP as the labor input for small, large, and all stores respectively. Hypothesis testing is conducted at the $5 \%$ level of significance.

The capital input $(\mathrm{K})$ is statistically significant in four of six alternative specifications in Table 1 . The $\mathrm{L}$ variable is statistically significant in large stores and all stores specifications, but not in the small stores specification. The COMP variable is statistically significant in all three categories (small stores, large stores and all stores). The technology parameter (constant) is statistically significant in all equations. If $\mathrm{K}$ is statistically significant then an increase in capital affects output holding other inputs constant. If $\mathrm{L}$ or $\mathrm{COMP}$ is statistically significant then an increase in labor will affect output holding other inputs constant. The coefficient for $\mathrm{K}\left(\beta_{1}\right)$ allows us to estimate the marginal product of capital while the coefficient for L or COMP $\left(\beta_{2}\right)$ allows us to estimate the marginal product of labor.

Specification (2) represents one of the production function estimates for small retail stores in the Philippines. It shows that technological change occurred in the Philippine retail trade sector from 
1983 to 2000 . It also indicates that a $1 \%$ increase in the capital input will increase output by $0.49 \%$. On the other hand, a $1 \%$ increase in the labor input will increase output by $0.39 \%$. Labor's share of value added for small stores is $45 \%$ while capital's share is $55 \%$. (The share of capital is computed as $\beta_{1} /\left(\beta_{1}+\beta_{2}\right)$ while the share of labor is computed as $\beta_{2} /\left(\beta_{1}+\beta_{2}\right)$.) Using specification (4) for large stores, we see that a $1 \%$ increase in capital input has no effect on output, while a $1 \%$ increase in compensation will increase output in large retail stores by $0.94 \%$. Labor share of value added is $87 \%$, and capital's share is $13 \%$ (although capital's coefficient is not statistically significant).

Table 2. Production Function Estimates of Philippine Retail Stores: 1983-2000.

\begin{tabular}{|c|c|c|c|c|c|c|}
\hline Variables & \multicolumn{2}{|c|}{ Small Stores } & \multicolumn{2}{c|}{ Large Stores } & \multicolumn{2}{c|}{ All Stores } \\
\hline & $(1)$ & $(2)$ & $(3)$ & $(4)$ & $(5)$ & $(6)$ \\
\hline \multirow{2}{*}{ Constant } & $\begin{array}{c}4.901^{\star} \\
(1.214)\end{array}$ & $\begin{array}{c}3.720^{\star} \\
(0.395)\end{array}$ & $\begin{array}{c}10.175^{\star} \\
(1.124)\end{array}$ & $\begin{array}{c}3.345^{\star} \\
(1.391)\end{array}$ & $\begin{array}{c}4.012^{\star} \\
(1.363)\end{array}$ & $\begin{array}{c}3.068^{\star} \\
(0.899)\end{array}$ \\
\hline $\mathrm{K}$ & $\begin{array}{c}0.665^{\star} \\
(0.115)\end{array}$ & $\begin{array}{c}0.485^{\star} \\
(0.115)\end{array}$ & $\begin{array}{c}0.292^{\star} \\
(0.116)\end{array}$ & $\begin{array}{c}0.023 \\
(0.109)\end{array}$ & $\begin{array}{c}0.701^{\star} \\
(0.120)\end{array}$ & $\begin{array}{c}0.367^{\star} \\
(0.120)\end{array}$ \\
\hline $\mathrm{L}$ & 0.538 & & $0.549^{\star}$ & & $1.013^{\star}$ & \\
& $(0.414)$ & & $(0.239)$ & & $0.338)$ & \\
\hline COMP & & $0.390^{\star}$ & & $0.944^{*}$ & & $0.596^{\star}$ \\
& & $(0.100)$ & & $(0.177)$ & & $(0.097)$ \\
\hline R-squared & 0.430 & 0.540 & 0.476 & 0.622 & 0.642 & 0.752 \\
\hline Adjusted R-squared & 0.409 & 0.523 & 0.457 & 0.608 & 0.629 & 0.743 \\
\hline SE of regression & 0.410 & 0.368 & 0.552 & 0.469 & 0.393 & 0.327 \\
\hline Durbin-Watson Statistic & 1.537 & 1.467 & 1.558 & 1.335 & 1.663 & 1.397 \\
\hline F-statistic & 20.739 & 32.246 & 24.988 & 45.189 & 49.386 & 83.510 \\
\hline t-statistic to test for CRS & $2.516^{\star}$ & -0.466 & -0.948 & -0.309 & 0.506 & -1.139 \\
\hline
\end{tabular}

Number of observations: 58

* Significant at 0.05 level

Note: Figures in parentheses refer to standard errors.

The hypothesis of constant returns to scale (Hypothesis 3) is not rejected for large stores. This hypothesis is tested by using the following equation:

$$
\text { (3) } t=\frac{\beta_{1}+\beta_{2}-H_{0}}{\operatorname{se}\left(\beta_{1}+\beta_{2}\right)}
$$

where and $\mathrm{H}_{0}=1$ (see Hypothesis 3 above). The derived t-statistic is then compared to the critical $\mathrm{t}$-value for the two-tailed test at the $5 \%$ level of significance and 55 degrees of freedom which is 2.005. If the absolute value of the t-statistic from equation (3) is less than the critical t-value of 2.005 then we do not reject the hypothesis of constant returns to scale. Otherwise, we reject the hypothesis. Looking at the computed t-statistics in Table 2, we only reject Hypothesis 3 for specification 1.

Using specification (6) as the "best" specification for the all stores category, we can conclude that a $1 \%$ increase in capital will lead to a $0.37 \%$ increase in output in all stores in the Philippine retail trade sector. On the other hand, a $1 \%$ increase in labor input (or compensation) will lead to a $0.60 \%$ increase in output in all retail stores. Thus, the productivity of labor is higher than that of capital when it comes to all retail stores. Labor share of value added in all stores is estimated to be $62 \%[0.596 /(0.366+0.596)]$ while capital's share is estimated to be $38 \%$. The t-statistics to test for constant returns to scale (CRS) show that the sum of the coefficients for labor and capital are not 
statistically different from unity except for specification (1). Labor is therefore more productive than capital in Philippine retail stores in general although it seems capital is more productive when it comes to small stores. Philippine retail stores are subject to constant returns to scale because the sum of the production coefficients is not statistically different from unity.

We reject Hypothesis 1 in all specifications except specification (4). Hypothesis 2 is rejected in all specifications except specification (1). Hypothesis 3 is not rejected for all specifications except specification (1) meaning that most of the specifications show constant returns to scale. The F-statistics for all specifications are significant. The Durbin-Watson statistics in Table 1 indicate that autocorrelation is not a problem at the $1 \%$ level in our regression estimates except for specification (4). However, not all of the employees in the data are paid employees. Also, compensation in our data is composed of salaries and wages as well as benefits. We try to find out if removing unpaid workers as well as benefits from our labor variable would change our results. The results from using paid employees might be similar to the results from using total employees. Also, the results from using wages and salaries alone might be similar to the results from using total compensation. However, it is still interesting to separate paid workers from unpaid workers and wages and salaries from benefits because production theory would prefer to link output with paid inputs which means a preference for salaries and wages over total compensation and paid employees over total employees. Table 3 shows the results if we adjust our labor data.

The L variable for Table 3 represents paid employees instead of total number of employees which we did in Table 2. The COMP variable in Table 3 now represents salaries and wages instead of total compensation. The results in Table 3 mostly resemble those of Table 2. There are a few differences though. One difference is that capital is significant in specification (3) of Table 2 while it is insignificant in specification (3) of Table 3. The estimate for capital is positive and insignificant in specification (4) of Table 2 while it is negative and insignificant in specification (4) of Table 3. Specification (3) and (4) show that capital is not much of a factor when it comes to large stores. Specification (5) in Table 2 shows that the coefficient of labor is higher than the coefficient of capital while the reverse is true for specification (5) in Table 3. The R-squared and adjusted R-squared values for all specifications in the small stores and all stores categories of Table 2 are higher than their counterparts in Table 3. The R-squared and adjusted R-squared values for large stores in Table 2 are lower than their Table 3 counterparts.

We reject Hypothesis 1 for all specifications except specification (3) and (4). We reject Hypothesis 2 for all specifications except for specification (1). Specification (1) in Table 3 shows constant returns to scale whereas specification (1) for Table 2 does not show constant returns to scale. We do not reject Hypothesis 3 for all specifications of Table 3. 
Table 3. Production Function Estimates of Philippine Retail Stores: 1983-2000 (using adjusted labor data).

\begin{tabular}{|c|c|c|c|c|c|c|}
\hline \multirow[t]{2}{*}{ Variables } & \multicolumn{2}{|c|}{ Small Stores } & \multicolumn{2}{|c|}{ Large Stores } & \multicolumn{2}{|c|}{ All Stores } \\
\hline & $(1)$ & $(2)$ & (3) & $(4)$ & $(5)$ & $(6)$ \\
\hline Constant & $\begin{array}{l}5.718^{\star} \\
(1.343)\end{array}$ & $\begin{array}{c}3.967^{\star} \\
(1.139)\end{array}$ & $\begin{array}{l}10.861^{\star} \\
(1.230)\end{array}$ & $\begin{array}{c}3.361^{\star} \\
(1.326)\end{array}$ & $\begin{array}{l}5.443^{\star} \\
(1.455) \\
\end{array}$ & $\begin{array}{l}3.240^{*} \\
(0.909)\end{array}$ \\
\hline $\mathrm{K}$ & $\begin{array}{l}0.639^{\star} \\
(0.127)\end{array}$ & $\begin{array}{c}0.457^{\star} \\
(0.122)\end{array}$ & $\begin{array}{c}0.226 \\
(0.131)\end{array}$ & $\begin{array}{l}-0.044 \\
(0.114)\end{array}$ & $\begin{array}{l}0.662^{*} \\
(0.137)\end{array}$ & $\begin{array}{l}0.328^{\star} \\
(0.127)\end{array}$ \\
\hline $\mathrm{L}$ & $\begin{array}{c}0.197 \\
(0.185)\end{array}$ & & $\begin{array}{l}0.632^{\star} \\
(0.251)\end{array}$ & & $\begin{array}{l}0.480^{*} \\
(0.184)\end{array}$ & \\
\hline COMP & & $\begin{array}{c}0.397^{\star} \\
(0.108)\end{array}$ & & $\begin{array}{l}1.019^{\star} \\
(0.179)\end{array}$ & & $\begin{array}{l}0.624^{*} \\
(0.105) \\
\end{array}$ \\
\hline R-squared & 0.424 & 0.528 & 0.485 & 0.638 & 0.630 & 0.745 \\
\hline Adjusted R-squared & 0.403 & 0.511 & 0.466 & 0.625 & 0.616 & 0.738 \\
\hline SE of regression & 0.412 & 0.373 & 0.547 & 0.459 & 0.400 & 0.331 \\
\hline Durbin-Watson Statistic & 1.517 & 1.505 & 1.493 & 1.240 & 1.406 & 1.459 \\
\hline F-statistic & 20.270 & 30.732 & 25.916 & 48.516 & 46.785 & 81.182 \\
\hline $\mathrm{t}$-statistic to test for CRS & 1.080 & -0.590 & -0.880 & -0.247 & -0.981 & -1.333 \\
\hline
\end{tabular}

Number of observations: 58 * Significant at 0.05 level

Note: Figures in parentheses refer to standard errors.

\section{DISCUSSION}

We have shown through hypothesis testing that for the all stores category, which represent the entire Philippine retail sector, both labor and capital are significant factors of production. For the all stores category the marginal product of labor is higher than the marginal product of capital. Therefore, for the all stores category in the short run, additional labor would be more productive than additional capital. This could be because of the fact that the retail sector is a service-oriented industry. We have also shown that for the all stores category there are constant returns to scale. This implies that the larger stores do not hold significant monopoly power over the entire retail sector and that the retail sector is relatively competitive. Larger stores are thus not necessarily more productive than smaller stores. The constant variable which represents technology is significant for all specifications in Tables 2 and 3. This shows that a change in technology will have an effect on output if capital and labor are held constant. 


\section{CONCLUSION}

The estimation of a Cobb-Douglas production function for Philippine retail stores has produced the following interesting findings: (1) the hypothesis that a change in capital input has no effect on a change in retail store output is rejected; (2) the hypothesis that a change in labor input has no effect on a change in retail store output is likewise rejected; (3) the hypothesis of constant returns to scale in Philippine retail stores cannot be rejected; (4) the superior productivity of labor as opposed to capital in Philippine retail stores is consistently confirmed; and (5) finally, there are indications that technological change is occurring in Philippine retail stores.

These findings are useful to retail store managers, government policy makers, and academic researchers monitoring the retail trade industry. Estimating a production function for the retail sector is important for retailers because the cost of marketing goods is influenced by the productivity of the retail sector. It will also give retailers the tools to compare productivity in the retail sector to productivity in other sectors of the economy. It would be useful to store managers to determine their scale of operation. They might wonder if doubling the size of their operations would lead to doubling the amount of labor and capital in their store. It would also help storeowners determine what their labor costs are as well as help them estimate their return on investment.

This paper's findings are somewhat similar to the results of Ingene and Lusch (1999) when they estimated a production function of American department stores using a Cobb-Douglas production function. They found the marginal product of labor to be higher than the marginal product of capital and they also did not reject the hypothesis of constant returns to scale.

However, several research questions remain unanswered. A richer database is needed to test the existence of economies of scale using an alternative methodology based on ratios derived from data on profits, inventory, gross margins, wages, sales, and capital as suggested by McClelland (1967). A more detailed database is required to estimate the production function of a specific retail store (e.g. supermarkets, department stores or drugstores). As data collection hopefully becomes better in the future more work could be done on this subject. These research questions are interesting topics for future research. 


\section{REFERENCES}

[1]Aigner, D.J. \& Chu, S.F. (1968). On estimating the industry production function. The American Economic Review, 58(4), 826-839.

[2]Assaf, A.G., Barros, C., \& Sellers-Rubio, R. (2011). Efficiency determinants in retail stores: A Bayesian framework. Omega, 39(2011), 283-292.

[3] Ayaz, S., \& Hussain, Z. (2011). Impact of institutional credit on production efficiency of farming sector: A case study of District Faisalabad. Pakistan Economic and Social Review, 49(2), 149-162.

[4]Chen, W., Niebel, T., \& Saam, M. (2016). Are intangibles more productive in ICT-intensive industries? Evidence from EU countries. Telecommunications Policy, 40(5), 471-484.

[5]Constantin, P. D., Martin, D. L., \& Rivera, E. B. B. R. (2009). Cobb-Douglas, translog stochastic production function and data envelopment analysis in total factor productivity in Brazilian agribusiness. Journal of Operations and Supply Chain Management, 2(2), 20-34.

[6]Digal, L.N. (2001). An analysis of the structure of the Philippine retail food industry. Philippine Journal of Development, 28(1), 13-54.

[7]Douglas, P.H. (1976). The Cobb-Douglas production function once again: Its history, its testing, and some new empirical values. Journal of Political Economy, 84(5), 903-915.

[8]Gauri, D.K. (2013). Benchmarking retail productivity considering retail pricing and format strategy. Journal of Retailing, 89(1), 1-14.

[9]Gujarati, D.N., Porter, D.C. \& Gunasekar, S. (2017). Basic econometrics (5th ed.). New York: McGraw-Hill.

[10]Hossain, M. M., Majumder, A. K., \& Basak, T. (2012). An application of non-linear CobbDouglas production function to selected manufacturing industries in Bangladesh. Open Journal of Statistics, 2(4), 460-468.

[11]Ingene, C.A. (1982). Labor productivity in retailing. Journal of Marketing, 46(4), 75-90.

[12]Ingene, C.A. \& Lusch, R.F. (1978, March). Estimation of an aggregate production function for U.S. retailing: 1951-1974. Paper presented at the Southwestern Marketing Association.

[13]Ingene, C.A. \& Lusch, R.F. (1999). Estimation of a department store production function. International Journal of Physical Distribution and Logistics Management, 29(7-8), 453-465.

[14]Kendrick, J. (1973). Postwar productivity trends in the United States: 1948-1969. New York: National Bureau of Economic Research.

[15]McAnally, A.P. (1963). The measurement of retail productivity. The Journal of Industrial Economics, 11(2), 87-95.

[16gMcClelland, W.G. (1967). Costs and competition in retailing. London: Macmillan.

[17]Ofer G. (1973). Returns to scale in retail trade. Review of Income and Wealth, 19(4), 363-384.

[18]Ratchford B.T. \& Brown, J.R. (1985). A study of productivity changes in food retailing. Marketing Science, 4(4), 292-311.

[19]Shin, S. \& Eksioglu, B. (2015). An empirical study of RFID productivity in the U.S. retail supply chain. International Journal of Production Economics, 163, 89-96.

[20]Takeuchi, H. \& Bucklin, L.P. (1977). Productivity in retailing: Retail structure and public policy. Journal of Retailing, 53(1), 35-46.

[21]Tilley, R.P.R. \& Hicks, R. (1970). Economies of scale in supermarkets. The Journal of Industrial Economics, 19(1), 1-5. 